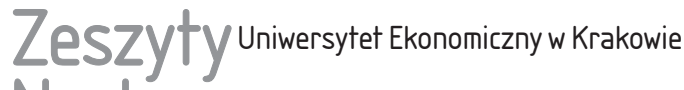 Naukowe
}

\section{Możliwości wykorzystania metody TVScore do oceny znakowania opakowań na przykładzie suplementów diety*}

\section{Streszczenie}

Rosnące znaczenie opakowań produktów w komunikacji rynkowej pomiędzy producentami dóbr a ich konsumentami sprawia, że niezwykle ważna okazuje się właściwa dostępność zamieszczonych na nich informacji. Celem artykułu jest przedstawienie metody TVScore, próba jej adaptacji do warunków krajowych oraz przeprowadzenie przy jej użyciu oceny oznakowania wybranych suplementów diety. Wybór tej grupy środków spożywczych do badań wynikał z takich czynników jak ciągle rosnąca sprzedaż tych produktów oraz wysoki poziom niezadowolenia konsumentów z ich oznakowania. Do oceny wytypowano dziewięć opakowań suplementów diety wspomagających odporność. Otrzymane wyniki pozwoliły na wskazanie, że w największej liczbie przypadków o niskiej dostępności oznakowania decydowała zbyt mała czcionka oraz połyskująca powierzchnia opakowań.

Słowa kluczowe: opakowanie, znakowanie, metoda badania, czytelność, widoczność. Klasyfikacja JEL: D83, M31.

\footnotetext{
Bartłomiej Kabaja, Uniwersytet Ekonomiczny w Krakowie, Katedra Opakowalnictwa Towarów, 31-510 Kraków, ul. Rakowicka 27, e-mail: kabajab@uek.krakow.pl

Publikacja stanowi wynik realizacji tematu badawczego dofinansowanego ze środków Ministerstwa Nauki i Szkolnictwa Wyższego przyznanych Wydziałowi Towaroznawstwa Uniwersytetu Ekonomicznemu w Krakowie na badania dla młodych naukowców oraz uczestników studiów doktoranckich.
} 


\section{Wprowadzenie}

Coraz większa konkurencja na rynku dóbr konsumpcyjnych doprowadziła do wzrostu podaży i dostępności produktów. Ich potencjalni nabywcy poddawani są coraz intensywniejszym działaniom mającym na celu promocję poszczególnych towarów.

Szczególnie istotnym narzędziem w komunikacji rynkowej jest opakowanie jednostkowe. Towarzyszy ono produktom w drodze od producenta do konsumentów i jest jednocześnie instrumentem przekazu najdłużej na nich oddziałującym [Nestorowicz 2014].

Opakowanie przez celowo nadaną formę przestrzenną (kształt), wielkość, barwę, grafikę oraz zastosowany materiał i formę konstrukcyjną spełnia funkcje związane z przekazem informacji [Cholewa-Wójcik i Kawecka 2015]. Na informacyjność opakowania składają się takie czynniki, jak: obecność i czytelność informacji obligatoryjnych i fakultatywnych ważnych z punktu widzenia prawa oraz potrzeb i oczekiwań konsumentów, zdolność sugerowania przez warstwę wizualną przeznaczenia produktu oraz umożliwienie łatwego odczytania informacji przez odpowiednie zastosowanie elementów warstwy wizualnej [Lisińska-Kuśnierz 2009].

Celem niniejszego opracowania jest prezentacja wyników badań empirycznych pozwalających na możliwość adaptacji metody TVScore zaproponowanej przez M. Metz [1996] do oceny różnych znaków zamieszczonych na opakowaniach produktów tworzących znakowanie oraz oceny informacyjności każdego opakowania.

\section{Stan badań w zakresie znakowania opakowań}

Projekty opakowań dóbr konsumpcyjnych powinny uwzględniać potrzeby i oczekiwania ich nabywców. Często stanowią jedyne źródło informacji o produkcie dla konsumentów zarówno w momencie dokonywania zakupu, jak i podczas jego użytkowania. Dobór treści przekazu i ich odpowiednia prezentacja muszą uwzględniać predyspozycje docelowej grupy odbiorców.

W ostatnim czasie kwestie dotyczące znakowania środków spożywczych i przekazywania informacji dotyczących żywności stały się przedmiotem zainteresowania najwyższych władz Unii Europejskiej. Przyjęte Rozporządzenie Parlamentu Europejskiego i Rady (UE) nr 1169/2011 w sprawie przekazywania konsumentom informacji na temat żywności ma na celu ujednolicenie przepisów we wszystkich krajach członkowskich oraz ich aktualizację w sposób 
uwzględniający zmiany, do których doszło w dziedzinie informacji na temat żywności.

Rozporządzenie (UE) nr 1169/2011 reguluje zakres znakowania oraz nakłada obowiązek umieszczania go w widocznym miejscu, w taki sposób aby było dobrze widoczne, czytelne oraz nieusuwalne. Informacje znajdujące się na opakowaniu nie mogą być w żaden sposób ukryte, zasłonięte, pomniejszone ani przerwane jakimikolwiek nadrukami, ilustracjami czy innym materiałem. Etykiety żywności powinny być ponadto jasne i zrozumiałe, aby były pomocne dla konsumentów.

Poza informacjami wymaganymi prawnie i jednocześnie warunkującymi dopuszczenie produktu do obrotu rynkowego producenci mogą umieszczać dodatkowe znaki na opakowaniach. Do najczęściej stosowanych dobrowolnych informacji należą: znaki towarowe, znaki ekologiczne oraz znaki związane z dobrowolną certyfikacją i programami promocyjnymi [Ucherek 2009].

R. Nestorowicz [2014] słusznie zauważa, że w większości przypadków układ informacji na opakowaniach dóbr konsumpcyjnych nie ma na celu zaspokojenia potrzeb informacyjnych konsumenta, lecz głównie nakłonienie go do zakupu danego produktu. Następstwem takiego podejścia jest umieszczanie niektórych komunikatów w mało widocznych miejscach, ich nieczytelność oraz trudności w zrozumieniu.

Prace I. Ozimek [2002] oraz M. Ucherek [2009] potwierdzają chęć konsumentów do korzystania z informacji znajdujących się na opakowaniach. Zakres i okoliczności posługiwania się znakowaniem uzależnione są od pewnych zmiennych, m.in. okoliczności kontaktu nabywcy z zapakowanym produktem. Jak wynika z badań I. Ozimek i M. Tomaszewskiej-Pielachy [2011], respondenci wykazują największe zainteresowanie treściami umieszczonymi na etykietach produktów podczas dokonywania zakupów (74\%). Mniejsza liczba badanych (54\%) deklaruje zwracanie uwagi na informacje zamieszczone na opakowaniu podczas przygotowywania produktu, a tylko niespełna połowa $(47 \%) \mathrm{w}$ chwili jego spożywania.

Na korzystanie z informacji znajdujących się na opakowaniach ma wpływ także rodzaj produktu. Oznakowanie takich wyrobów jak mięso oraz mleko spotyka się z dużo większym zainteresowaniem ze strony nabywców niż oznakowanie kawy, herbaty czy napojów alkoholowych [Ozimek i Tomaszewska-Pielacha 2011].

Ze względu na konieczność określenia potrzeb informacyjnych potencjalnych konsumentów niezwykle istotna okazuje się identyfikacja ważności poszczególnych znaków obligatoryjnych i fakultatywnych znajdujących się na opakowaniach produktów. 
Badania w tym zakresie prowadziły m.in.: M. Tomaszewska-Pielacha i I. Ozimek [2011] oraz M. Ankiel-Homa [2012]. Na podstawie badań konsumentów czekolad, należących do grupy artykułów spożywczych częstego zakupu, cieszących się dużą popularnością, M. Lisińska-Kuśnierz [2009] określiła hierarchię ważności informacji. Za najważniejsze uznała znaki dotyczące marki i producenta, a następnie daty minimalnej trwałości, nazwy i wartości odżywczej.

Określenie potrzeb i wymagań potencjalnych nabywców w zakresie znakowania opakowań staje się niezwykle istotne dla zaangażowanych podmiotów wprowadzających produkty na rynek. Badania przeprowadzone przez M. Klonowską-Matynię [2010], polegające m.in. na porównaniu ocen konsumentów i producentów w zakresie pewnych aspektów opakowań oraz poglądów producentów na ten temat, pozwoliły na stwierdzenie, że przekonania dotyczące zachowań i determinant zakupu w tych grupach są odmienne.

Małe zaangażowanie w procesie projektowania opakowań oraz doboru odpowiednich form przekazu komunikatu rynkowego ze strony podmiotów wprowadzających produkty do obrotu zdają się potwierdzać także inne badania. Prace M. Lisińskiej-Kuśnierz, M. Ucherek i A. Borusiewicz [2008] oraz M. Miśniakiewicz i M. Pycek [2014] wykazały nieprawidłowości w zakresie spełnienia wymagań prawnych dotyczących obecności obligatoryjnego znakowania na produktach częstego zakupu, takich jak: czekolady, soki jabłkowe, jogurty naturalne i ciastka.

Skalę problemu pokazują także coroczne wyniki kontroli publikowane przez Inspekcję Jakości Handlowej Artykułów Rolno-Spożywczych. Według danych za 2014 r. odsetek skontrolowanych produktów, w przypadku których odnotowano nieprawidłowości w oznakowaniu, wyniósł $24 \%$. Najczęstsze odstępstwa dotyczyły przekazywania takich informacji, jak: nazwa produktu, skład, pochodzenie, sugerowanie szczególnych właściwości [Sprawozdanie roczne... 2015].

Nieobecność informacji obligatoryjnych na opakowaniach handlowych to tylko jeden z przykładów nieprawidłowości wpływających na obniżenie poziomu informacyjności przekazu rynkowego kierowanego do konsumentów. Przeprowadzone badania potwierdzają, że konsumenci nisko oceniają widoczność i czytelność informacji umieszczanych na opakowaniach oraz mają trudności z jej zrozumieniem.

Prace M. Tomaszewskiej-Pielachy i I. Ozimek [2011] wskazują, że tylko ok. 30\% badanej populacji uznaje znakowanie opakowań żywności za czytelne i łatwe do zrozumienia. Pozostali ankietowani jako główne utrudnienia w dostępności informacji wskazywali: stosowanie zbyt małej czcionki, mały kontrast pomiędzy barwą czcionki a tłem oraz słabą jakość druku.

Badania przeprowadzone wśród osób cierpiących na alergię pokarmową potwierdziły, że produkty spożywcze nie są oznakowane w sposób właściwy. Około $82 \%$ respondentów uznało, że informacje na opakowaniach żywności dotyczące alergenów są przedstawione w sposób niepełny i nieprawidłowy, głównie 
z powodu braku precyzyjnych i zrozumiałych danych o składzie produktu [Piecyk i Marczuk-Daniluk 2011].

Przedstawione wyniki badań pozwalają stwierdzić, że poziom zadowolenia ze znakowania opakowań występujących w obrocie rynkowym jest stosunkowo niski i w przypadku niektórych produktów nie gwarantuje konsumentom bezpieczeństwa. Zarówno świadomość potrzeby dokonywania zmian, jak i działania przedsiębiorstw podejmowane w tym zakresie są niewystarczające.

W rozwiązaniu tego problemu pomocne może okazać się stosowanie prostych metod umożliwiających przeprowadzenie oceny znakowania. Przykładem takiego narzędzia jest TVScore. Ze względu na trudności określone na podstawie analizy badań, jak i niepokojące wyniki prac własnych autora za cel badań obrano prezentację metody TVScore oraz jej adaptację do warunków panujących na rynku krajowym.

\section{Metoda TVScore}

Metoda TVScore (typography variable score) została opracowana przez M. Metz [1996]. Opiera się na założeniu, że typografia tekstu umieszczonego na opakowaniach produktów ma fundamentalne znaczenie w procesie czytania tych treści przez konsumentów, zaś właściwe odczytanie informacji jest warunkiem koniecznym do ich poprawnego zrozumienia. Pojęciem typografii w węższym znaczeniu określa się zwykle graficzne kształtowanie tekstu za pomocą dostępnych krojów pisma. Natomiast w szerszym znaczeniu pojęcie typografii można rozumieć również jako projektowanie rozkładu ilustracji i innych elementów graficznych w obrębie projektowanej struktury i tak należy ją rozumieć w niniejszej pracy.

Założenia metody TVScore wynikają z licznych badań polegających na optymalizacji parametrów druku tekstu w celu uzyskania możliwie jak największej jego przystępności dla odbiorcy. Badania takie prowadzili m.in.: D.G. Paterson i M.A. Tinker [1940], M.A. Tinker [1963], a także S.W. Sutherland [1989].

Metoda wykorzystuje zone of optimal typography (ZOT) [Sutherland 1989] jako zbiór zaleceń opisujących parametry tekstu gwarantujące możliwość sprawnego odczytania. Odstępstwa od zaleceń traktowane są jako błędy. Za każdy błąd przyznawane są punkty, dlatego im więcej punktów uzyska badane opakowanie, tym trudniejsze do odczytania są informacje na nim umieszczone.

Wyniki analizy przeprowadzonej tą metodą wykazały istotną statystycznie zależność między łatwością czytania tekstu (za pomocą miscue analysis) a oceną atrakcyjności opakowań dokonaną przez konsumentów [Metz 1996]. Etykiety 
z niską oceną TVScore (bliższą ZOT) były konsekwentnie oceniane jako bardziej atrakcyjne i łatwiejsze do przeczytania niż etykiety z wysoką oceną TVScore.

Przydatność metody oraz jej aplikacyjny charakter potwierdzają liczne zastosowania w gospodarce, o czym mówi m.in.: raport Readability of Food Product Labels sporządzony dla Consumer Interest Alliance Inc. z siedzibą w Toronto [Mackey i Metz 2007].

Analiza reguł oceny oraz przegląd wyników przeprowadzonych do tej pory badań pozwoliły autorowi na nieznaczną modyfikację metody mającą na celu jej dostosowanie do warunków panujących na krajowym rynku dóbr konsumpcyjnych i umożliwienie wykorzystania w praktyce.

Poniżej przedstawiono kryteria oceny znakowania opakowań, do których należą cechy związane z drukowanym tekstem i jego organizacją [Metz 1996, Mackey i Metz 2007].

Styl druku. W projektowaniu opakowań akceptowane są czcionki zarówno szeryfowe, jak i bezszeryfowe. Natomiast stosowanie zagęszczonego druku jest traktowane jako odstępstwo. Celem takiego działania jest umieszczenie informacji na mniejszej powierzchni. Nadmiernie zwarte litery tekstu znacznie utrudniają jednak jego odczytanie. Występowanie zagęszczonej czcionki, w której pozostają odstępy między literami, uznawane jest za nieznaczne odstępstwo i przyznawany jest 1 pkt. Jeśli litery stykają się ze sobą, traktuje się to jako znaczne odstępstwo od ZOT i przyznaje się 2 pkt.

Rozmiar czcionki. Rozmiar druku to odległość pomiędzy podstawową linią pisma a linią wersalika. Przyrządem do pomiaru tego parametru jest typometr. Rozmiar czcionki o wielkości co najmniej 8 pkt jest uznawany za wartość optymalną - najbardziej pożądaną. Wielkość liter poniżej 8 pkt traktowana jest jako odstępstwo, ponieważ znacznie utrudnia czytanie tekstu. Oznakowanie opakowań o wielkości czcionki pomiędzy 7 pkt a 7,5 pkt stanowi nieznaczne odstępstwo (przyznaje się 1 pkt). Rozmiar czcionki pomiędzy 6 pkt a 6,5 pkt to już znaczne odstępstwo (przyznaje się 2 pkt). Czcionki mniejsze niż 6 pkt otrzymują następującą punktację: przy wielkości czcionki 5-5,5 pkt przyznaje się 3 pkt, a przy wielkości mniejszej niż 5 pkt przyznaje się 4 pkt.

Odstęp między wierszami. Odległość między liniami pisma jest oznaczana w procentach jako stosunek jej długości do rozmiaru czcionki. Wartość optymalna to co najmniej $120 \%$. W przypadku wartości tego parametru wynoszącej od $119 \%$ do $100 \%$ przyznawany jest $1 \mathrm{pkt}$, ponieważ uznaje się to za nieznaczne odstępstwo. Wartość parametru poniżej 100\% traktowana jest jako znaczne odstępstwo i przyznaje się 2 pkt. W przypadku występowania szczególnych warunków rewersu druku (w kontrze) lub tekstu, w którym użyto majuskuły (wielkich liter), minimalną akceptowaną wartością parametru jest $120 \%$. Jeśli wartość ta jest niższa, przyznaje się 2 pkt. 
Pogrubienia i kursywa. Używanie w tekście pogrubień i kursywy w nagłówkach lub kluczowych słowach, których celem jest zwrócenie uwagi czytelnika, uznawane jest za pożądany element projektu opakowania. Natomiast brak użycia form mogących ułatwiać dostrzeżenie ważnych informacji lub stosowanie ich w całych wierszach stanowi nieznaczne odstępstwo. Jeśli wyróżnienie nagłówków i kluczowych słów nie występuje lub dotyczy więcej niż wybranych słów, ale nie więcej niż dwóch wierszy tekstu, przyznawany jest 1 pkt. Zastosowania pogrubień lub kursywy do więcej niż dwóch wierszy tekstu stanowi znaczne odstępstwo, ponieważ w znacznym stopniu utrudnia odbiór i ogranicza czytelność, dlatego przyznawane są 2 pkt.

Czcionka. Tekst znajdujący się na opakowaniach może być przedstawiony z wykorzystaniem wielkich liter (majuskuły), kapitalików, małych liter (minuskuły) oraz ich dowolnych kombinacji. Stosowanie tylko wielkich liter i kapitalików znacznie utrudnia jego odczytanie. Uznaje się to za znaczne odstępstwo i przyznaje się 2 pkt. Jeżeli wielkie litery i kapitaliki występują w większej części tekstu, przyznaje się 1 pkt. Optymalne wykorzystanie wielkich liter i kapitalików ma miejsce wtedy, gdy stosuje się je dla zwrócenia uwagi na ważne słowa i zdania, których konsument nie powinien przeoczyć.

Długość linii tekstu. Długość wierszy tekstu jest mierzona w pica (1 pica $=$ $=1 / 6$ cala $=4,2333 \mathrm{~mm}$ ). Zbyt długie lub zbyt krótkie linie tekstu utrudniają jego czytanie, a co za tym idzie - zrozumienie jego sensu. Za optymalną długość wierszy w przypadku umieszczania ich na opakowaniach produktów konsumpcyjnych przyjmuje się 14-28 pica. Stosowanie linii tekstu o długości powyżej 28 pica oraz z przedziału od 13 pica do 7 pica traktowane jest jako nieznaczne odstępstwo (przyznaje się $1 \mathrm{pkt}$ ). Krótkie linie o długości mniejszej niż 7 pica to znaczne odstępstwo od poziomu optymalnego, dlatego przyznaje się w takiej sytuacji 2 pkt. Jeśli linie pisma mają taką długość, która wymaga odwracania lub przekręcania opakowania w celu odczytania tekstu, stanowi to znaczne odstępstwo.

Wyrównanie tekstu. Wyrównanie tekstu do lewej strony to sposób najbardziej pożądany, powodujący powstawanie najmniejszej liczby pomyłek podczas czytania. Uznaje się je za rozwiązanie optymalne. Natomiast wyjustowanie tekstu wpływa na powstawanie odstępów między wyrazami i literami, które utrudniają jego odczytanie. Jest to traktowane jako nieznaczne odstępstwo i przyznaje się 1 pkt. Wyśrodkowywanie tekstu, wyrównanie do prawej strony i nadawanie mu kształtów geometrycznych (np. rombu) uznaje się za znaczne odstępstwo i przyznaje się 2 pkt.

Organizacja tekstu. Właściwa organizacja tekstu może być uzyskana na kilka sposobów, m.in. przez użycie pogrubień, kursywy, majuskuły do oznaczenia nagłówków, grup informacji i kluczowych słów w tekście, numerowanie i wyliczanie kolejnych kroków, stosowanie ramek, podkreśleń. Głównym celem 
jest łatwość odnalezienia ważnych informacji, ich odczytania oraz zrozumienia. Korzystanie z wymienionych sposobów organizacji tekstu to rozwiązanie optymalne. Częściowe wyróżnienie niektórych grup informacji z wykorzystaniem nielicznych sposobów opisanych powyżej skutkuje przyznaniem 1 pkt. W przypadku braku organizacji tekstu, braku nagłówków i wyróżnień, występowania nagłowników na końcach linii, braku odstępów i oddzielenia grup informacji przyznaje się 2 pkt.

Kontrast. Jest to stosunek barwy czcionki do barwy tła, na którym została wydrukowana. Parametr ten dla potrzeb TVScore wyrażany jest w procentach. Kontrast czarnych liter na białym tle wynosi $100 \%$. Pomiar kontrastu polega na wykorzystaniu skali szarości o określonej grubości punktów naniesionych na transparentną folię. Większość typometrów posiada taką skalę. Przez jej nałożenie na badany obszar dokonuje się pomiaru kontrastu. Jego wartość równa jest gęstości skali, przy której podczas poruszania nią po badanej powierzchni nie da się rozróżnić tła i tekstu. Optymalny poziom kontrastu to co najmniej $80 \%$. W przypadku osiągnięcia wartości niższych niż $80 \%$, a nie mniejszych niż $75 \%$ projekt otrzymuje 1 pkt. Jeśli poziom kontrastu wynosi od $74 \%$ do $70 \%$ przyznawane są 2 pkt. Za każde zmniejszenie kontrastu o dodatkowe 5\% dodawany jest 1 pkt.

Rewers druku. Druk wykonany czarnymi literami na białym lub kremowym tle jest najłatwiejszy do odczytania. Rewers druku lub druk w kontrze to zastosowanie białych liter na czarnym tle czy też szerzej czcionek o jasnych barwach na ciemniejszych tłach. Zastosowanie takiego sposobu wymaga od projektanta użycia większych rozmiarów czcionek i odpowiednich odstępów między liniami. Użycie rewersu druku jest niepożądane ze względu na dostępność informacji. Traktuje się je jako znaczne odstępstwo i przyznaje 2 pkt. Nieodpowiednie jest przede wszystkim stosowanie barw czcionki i tła należących do tej samej grupy. Należy unikać zwłaszcza barwy niebieskiej i fioletowej, gdyż znacznie utrudniają odczytanie tekstu. Należy pamiętać, że proces prawidłowego widzenia wymaga 300\% więcej światła u osób w wieku 60 lat niż u dwudziestolatków. Rewers druku może być stosowany co najwyżej do małych fragmentów tekstu przy zachowaniu odpowiedniego kontrastu pomiędzy czcionką a tłem (80\% i więcej). W takim przypadku stanowi on nieznaczne odstępstwo i przyznawany jest $1 \mathrm{pkt}$.

Powierzchnia opakowania. Powierzchnie opakowań, które odbijają światło, znacznie utrudniają proces czytania. Szczególnie gdy tekst jest barwy złotej lub srebrnej, powoduje to zlewanie się liter i ogranicza dostępność wizualną informacji. Wykorzystywanie powierzchni matowych, nieodbijających światła ułatwia czytanie i stanowi poziom optymalny. Zastosowanie lekko połyskujących powierzchni obniża dostępność informacji, przez co stanowi nieznaczne 
odstępstwo, w przypadku którego przyznaje się 1 pkt. Drukowanie tekstu na błyszczących materiałach wysoce utrudniających czytanie stanowi znaczne odstępstwo, szczególnie jeżeli opakowanie wymaga od konsumenta poruszania nim i odwracania w celu zmiany kąta padania światła. W takim przypadku przyznawane są 2 pkt.

Jakość wydruku. Niejednokrotnie nawet najlepszy projekt graficzny opakowania może nie przynieść oczekiwanego rezultatu ze względu na błędy powstałe w procesie drukowania. Często spotkać można nieprawidłowości, których przyczyną jest niewłaściwy druk. Za poziom optymalny przyjmuje się druk, który jest czysty i przejrzysty. Nieznacznie rozmyte krawędzie liter, lekko rozmazany tekst utrudniający odczytanie należy zakwalifikować jako nieznaczne odstępstwo i przyznać 1 pkt. W sytuacji gdy czcionka jest rozmazana, nieostra, a wyblakły druk uniemożliwia rozpoznanie liter i odczytanie słów, przyznawane są 2 pkt.

Tło druku. Druk powinien być umiejscowiony na jednolitym tle, nieutrudniającym czytania. Lokalizacja treści na grafice, znakach wodnych lub przezroczystej foli, dla której tło stanowi sam produkt, znacznie utrudnia odbiór. W sytuacji gdy tekst jest umieszczony na grafice nieznacznie utrudniającej jego przeczytanie, przyznawany jest 1 pkt. Grafikę i tło, które znacznie zakłócają odbiór i uniemożliwiają odczytanie treści, uznaje się za znaczne odstępstwo i przyznaje się 2 pkt.

Dzielenie wyrazów. Etykiety powinny być zaprojektowane w taki sposób, aby nie występowało dzielenie wyrazów między wierszami. Pojawienie się podzielonych wyrazów oznacza odstępstwo. Gdy występują one sporadycznie w ocenianym tekście, przyznawany jest 1 pkt. Kiedy dzielenie wyrazów pojawia się często, projekt otrzymuje 2 pkt.

Występowanie skrótów. Skróty pojawiające się w tekście utrudniają jego zrozumienie i często wywołują dezorientację. Dobrze zaprojektowane opakowanie nie powinno zawierać skrótów. Sporadycznie występujące akronimy stanowią nieznaczne odstępstwo i powodują przyznanie 1 pkt projektowi. W przypadku częstego występowania skrótów należy przyznać 2 pkt.

Zestawienie odstępstw oraz kryteriów, z uwzględnieniem których przeprowadza się ocenę TVScore, zostało przedstawione w tabeli 1.

Zgodnie z interpretacją zaproponowaną przez M.A. Mackey i M. Metz [2007] pojawienie się dwóch znacznych odstępstw powoduje, że projekt szaty graficznej opakowania nie może być zaakceptowany w aspekcie jego znakowania. Natomiast dwa nieznaczne odstępstwa są równoznaczne z jednym znacznym. W związku z tym cztery nieznaczne odstępstwa również powodują brak akceptacji ocenianego projektu szaty graficznej w aspekcie jego znakowania. 
Tabela 1. Kryteria oceny TVScore

\begin{tabular}{|c|c|c|c|}
\hline \multirow{2}{*}{ Kryteria } & Poziom optymalny & Nieznaczne odstępstwo & Znaczne odstępstwo \\
\hline & $0 \mathrm{pkt}$ & $1 \mathrm{pkt}$ & 2 pkt i więcej \\
\hline $\begin{array}{l}\text { Odstępy między } \\
\text { znakami tekstu }\end{array}$ & $\begin{array}{l}\text { Normalne, zgodne } \\
\text { z rozmieszczeniem } \\
\text { w danej czcionce }\end{array}$ & $\begin{array}{l}\text { Zagęszczone, pomię- } \\
\text { dzy literami pozostaje } \\
\text { odstęp }\end{array}$ & $\begin{array}{l}\text { Zagęszczone, litery } \\
\text { stykają się ze sobą }\end{array}$ \\
\hline Rozmiar czcionki & Co najmniej 8 pkt & $7-7,5 \mathrm{pkt}$ & $\begin{array}{l}6-6,5 \mathrm{pkt}=2 \\
5-5,5 \mathrm{pkt}=3 \\
\text { mniej niż } 5 \mathrm{pkt}=4\end{array}$ \\
\hline $\begin{array}{l}\text { Odstępy między } \\
\text { wierszami }\end{array}$ & Co najmniej $120 \%$ & $\begin{array}{l}\text { Mniej niż } 120 \% \text { do } \\
100 \%^{\mathrm{a}}\end{array}$ & Mniej niż 100\% \\
\hline $\begin{array}{l}\text { Pogrubienia } \\
\text { i kursywa }\end{array}$ & $\begin{array}{l}\text { Tylko nagłówki, ważne } \\
\text { słowa }\end{array}$ & $\begin{array}{l}\text { Brak użycia lub wyko- } \\
\text { rzystanie do } 2 \text { wierszy }\end{array}$ & Więcej niż 2 wiersze \\
\hline $\begin{array}{l}\text { Czcionka (maju- } \\
\text { skuła i kapitaliki) }\end{array}$ & $\begin{array}{l}\text { Najważniejsze słowa } \\
\text { i zdania }\end{array}$ & $\begin{array}{l}\text { Większość tekstu napi- } \\
\text { sana wielkimi literami }\end{array}$ & $\begin{array}{l}\text { Cały tekst napisany } \\
\text { wielkimi literami }\end{array}$ \\
\hline $\begin{array}{l}\text { Długość wiersza } \\
\text { tekstu }\end{array}$ & 14-28 Pica & $\begin{array}{l}\text { Powyżej } 28 \text { pica lub } \\
7-13 \text { pica }\end{array}$ & Mniej niż 7 pica \\
\hline $\begin{array}{l}\text { Wyrównanie } \\
\text { tekstu }^{\mathrm{b}}\end{array}$ & Do lewej strony & Wyjustowany & $\begin{array}{l}\text { Wyśrodkowany, wyrów- } \\
\text { nany do prawej lub } \\
\text { profilowany }\end{array}$ \\
\hline $\begin{array}{l}\text { Organizacja } \\
\text { tekstu }\end{array}$ & $\begin{array}{l}\text { Przejrzysta, umożli- } \\
\text { wiająca oddzielenie } \\
\text { informacji, występują } \\
\text { wyróżnienia ważnych } \\
\text { słów, np. tekst w ram- } \\
\text { kach, kolorowe tło } \\
\text { tekstu, krój pisma }\end{array}$ & $\begin{array}{l}\text { Częściowe wyróżnie- } \\
\text { nie niektórych grup } \\
\text { informacji }\end{array}$ & $\begin{array}{l}\text { Brak organizacji, } \\
\text { nagłówki na końcu linii, } \\
\text { bez odstępów, tekst } \\
\text { w jednej bryle }\end{array}$ \\
\hline Kontrast $^{\mathrm{c}}$ & $80 \%$ i więcej & $75 \%-79 \%$ & $\begin{array}{l}70 \%-74 \%, \text { poniżej } 70 \% \\
\text { za każde dodatkowe } 5 \% \\
-1 \text { pkt }\end{array}$ \\
\hline Rewers druku & $\begin{array}{l}\text { Ciemne litery na jasnym } \\
\text { tle }\end{array}$ & $\begin{array}{l}\text { Jasne litery na ciemnym } \\
\text { tle przy zachowaniu } \\
\text { optymalnego kontrastu }\end{array}$ & $\begin{array}{l}\text { Jasne litery na ciemnym } \\
\text { tle }\end{array}$ \\
\hline $\begin{array}{l}\text { Powierzchnia } \\
\text { opakowania }\end{array}$ & $\begin{array}{l}\text { Matowa, brak odbicia } \\
\text { światła od powierzchni } \\
\text { opakowania }\end{array}$ & $\begin{array}{l}\text { Lekko połyskująca, } \\
\text { powodująca } \\
\text { niewielkie trudności } \\
\text { w czytaniu }\end{array}$ & $\begin{array}{l}\text { Błyszcząca, znacznie } \\
\text { utrudniająca czytanie, } \\
\text { wymagająca zmiany } \\
\text { kąta nachylenia } \\
\text { opakowania w trakcie } \\
\text { czytania }\end{array}$ \\
\hline Jakość wydruku & Tekst czysty, przejrzysty & $\begin{array}{l}\text { Nieznacznie rozmyte } \\
\text { krawędzie liter, lekko } \\
\text { rozmazany tekst, } \\
\text { nieznacznie wyblakły } \\
\text { utrudniający odczytanie }\end{array}$ & $\begin{array}{l}\text { Rozmyte krawędzie } \\
\text { liter, tekst rozmazany, } \\
\text { nieostry, wyblakły } \\
\text { uniemożliwiający } \\
\text { odczytanie }\end{array}$ \\
\hline
\end{tabular}


cd. tabeli 1

\begin{tabular}{|l|l|l|l|}
\hline \multirow{2}{*}{ Kryteria } & \multicolumn{1}{|c|}{ Poziom optymalny } & Nieznaczne odstępstwo & \multicolumn{1}{|c|}{ Znaczne odstępstwo } \\
\cline { 2 - 4 } & \multicolumn{1}{|c|}{ pkt } & \multicolumn{1}{c|}{ pkt } & pkt i więcej \\
\hline $\begin{array}{l}\text { Umieszczanie } \\
\text { informacji na tle } \\
\text { utrudniającym } \\
\text { czytanie }\end{array}$ & $\begin{array}{l}\text { Tekst umieszczony na } \\
\text { jednolitym tle }\end{array}$ & $\begin{array}{l}\text { Tekst umieszczony na } \\
\text { grafice nieznacznie } \\
\text { utrudniającej jego } \\
\text { odczytanie }\end{array}$ & $\begin{array}{l}\text { Tekst umieszczony na } \\
\text { grafice znacznie utrud- } \\
\text { niającej jego odczytanie }\end{array}$ \\
\hline $\begin{array}{l}\text { Dzielenie wyra- } \\
\text { zów }\end{array}$ & Nie występuje & $\begin{array}{l}\text { Występuje } \\
\text { sporadycznie }\end{array}$ & Występuje często \\
\hline $\begin{array}{l}\text { Występowanie } \\
\text { skrótów }\end{array}$ & Nie występują & $\begin{array}{l}\text { Występują } \\
\text { sporadycznie }\end{array}$ & Występują często \\
\hline
\end{tabular}

a W przypadku występowania rewersu druku i majuskuły interlinia poniżej $120 \%$ jest uznawana za znaczne odstępstwo (2 pkt). ${ }^{\mathrm{b}}$ Jeżeli linie tekstu są tak długie, że wymagają odwracania opakowania w trakcie czytania, jest to uznawane za znaczne odstępstwo (2 pkt). ${ }^{\mathrm{c}}$ Należy unikać barw niebieskiej i fioletowej ze względu na utrudnione dostrzeganie tych barw wraz z wiekiem.

Źródło: opracowanie własne na podstawie [Metz 1996, Mackey i Metz 2007].

\section{Materiał badawczy}

Jako materiał badawczy w niniejszej pracy przyjęto dziewięć opakowań jednostkowych suplementów diety. Wybór podyktowany był niepokojącymi wynikami badań własnych, które świadczyły o znacznych trudnościach, jakie napotykają konsumenci tych produktów. Osoby stosujące suplementy diety miały trudności związane ze złą widocznością oznakowania, ograniczoną czytelnością treści oraz niezrozumieniem informacji umieszczonych na opakowaniach (rys. 1).

Kolejnymi przesłankami przemawiającymi za wyborem tej grupy środków spożywczych były notowana od kilku lat stale rosnąca sprzedaż tych produktów i zwiększająca się popularność niemal we wszystkich grupach wiekowych konsumentów.

Wykorzystane do badań suplementy diety reprezentowały środki o działaniu wspomagającym odporność. Produkty te stanowią najpopularniejszą grupę spośród wszystkich preparatów nabywanych przez konsumentów [Lisińska-Kuśnierz i Kabaja 2015].

Wytypowane do przeprowadzenia oceny TVScore opakowania suplementów diety miały kształt prostopadłościanów, wykonane były z tektury litej, a ich powierzchnia miała połyskującą fakturę. Szczegółowy opis każdego z opakowań zaprezentowano w tabeli 2.

Do oceny TVScore wybrano pięć znaków tworzących kod obligatoryjny opakowania: datę minimalnej trwałości, sposób stosowania, wykaz wszystkich składników, informację o porcji produktu zalecanej do spożycia w ciągu dnia oraz ostrzeżenie dotyczące nieprzekraczania zalecanej porcji dziennej. 


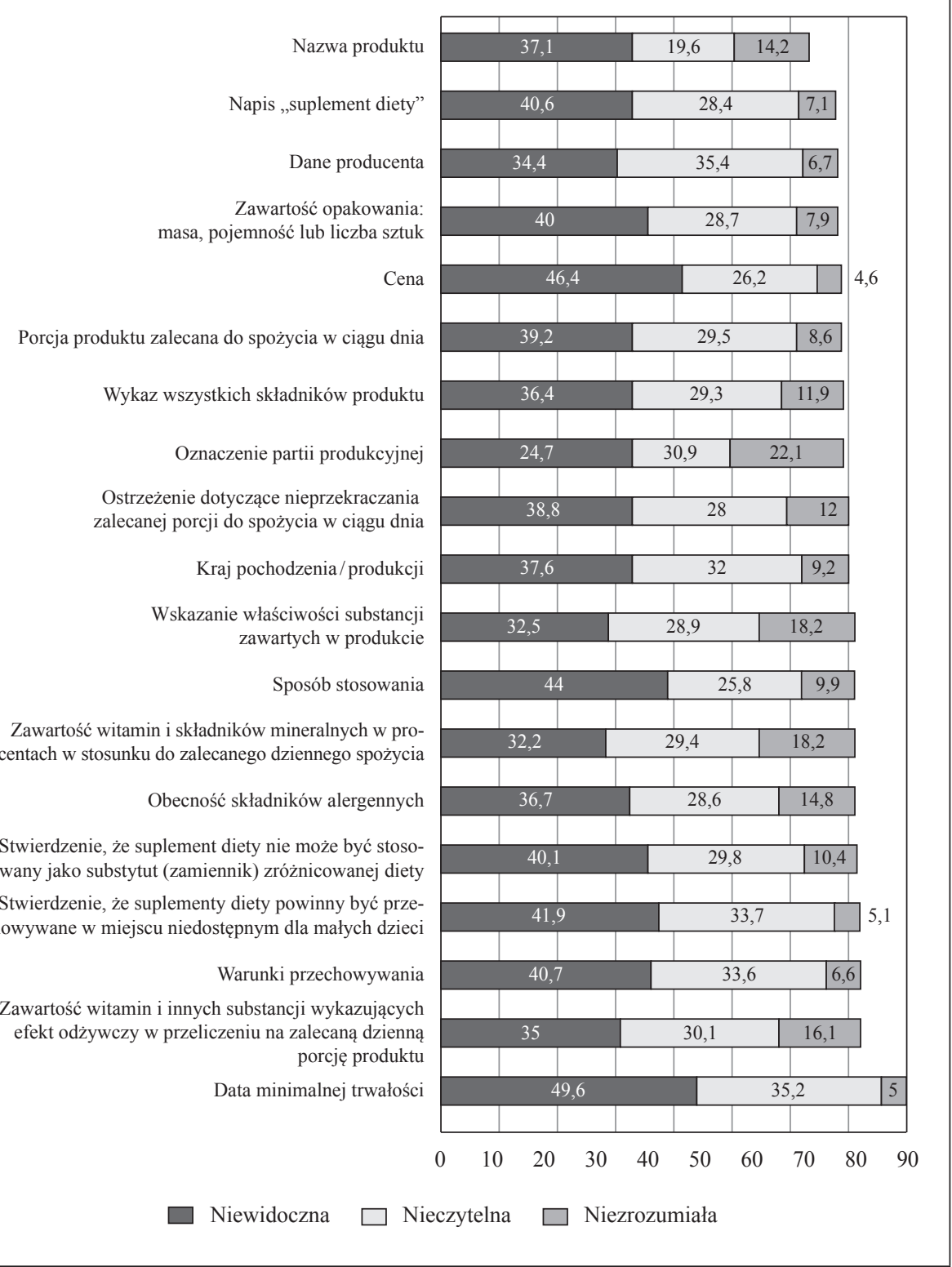

Rys. 1. Poziom nieprawidłowości dotyczący znakowania opakowań suplementów diety (w \%)

Źródło: opracowanie danych na podstawie [Lisińska-Kuśnierz i Kabaja 2015]. 


\begin{tabular}{|c|c|c|c|c|c|}
\hline 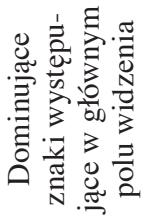 & 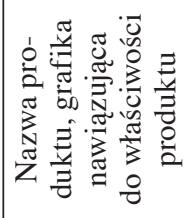 & 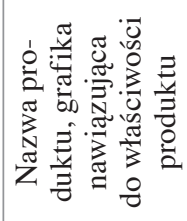 & 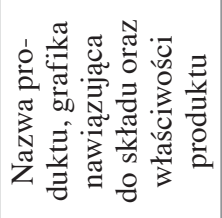 & 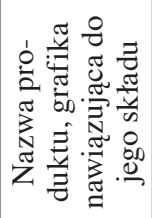 & 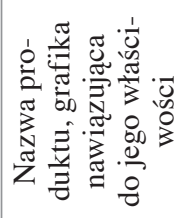 \\
\hline 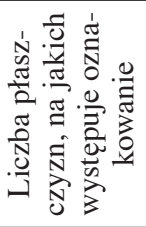 & 10 & 0 & 0 & 0 & 0 \\
\hline 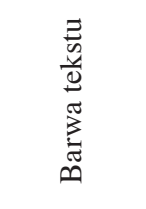 & \begin{tabular}{|l} 
: \\
芯 \\
N
\end{tabular} & 节 & 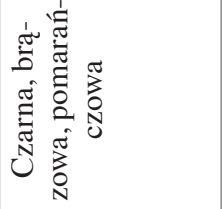 & 胥 & 节 \\
\hline 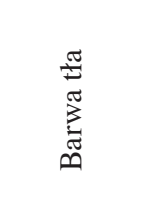 & 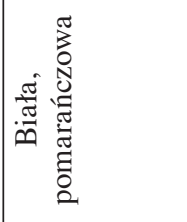 & 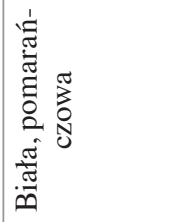 & 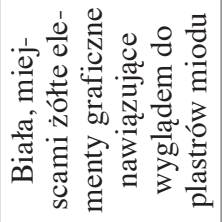 & 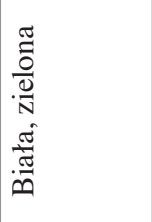 & 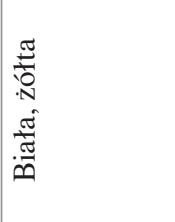 \\
\hline 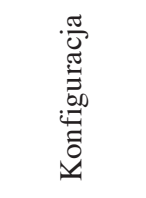 & 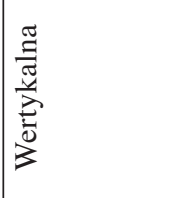 & 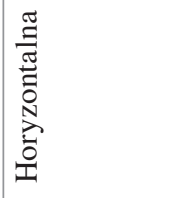 & 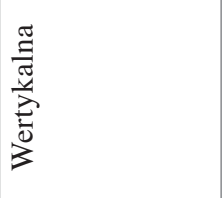 & 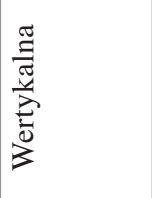 & 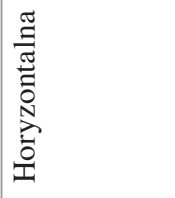 \\
\hline 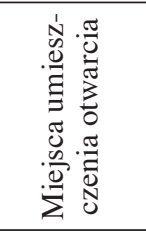 & 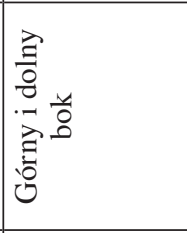 & 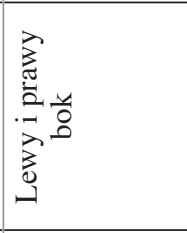 & 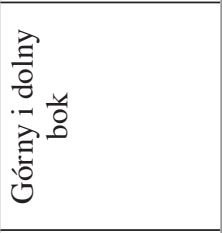 & 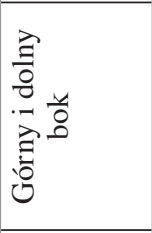 & 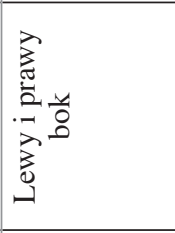 \\
\hline 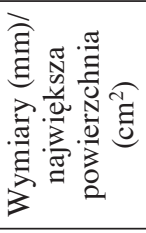 & 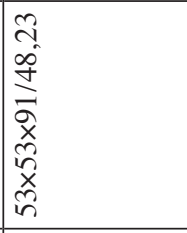 & $\begin{array}{l}0 \\
0 \\
0 \\
0 \\
0 \\
x \\
n \\
\hat{x} \\
x \\
0 \\
=\end{array}$ & 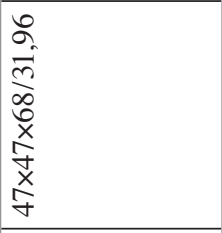 & 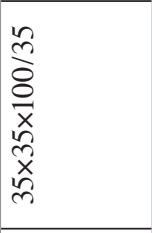 & 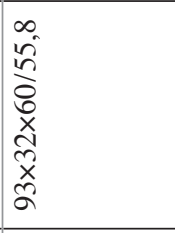 \\
\hline 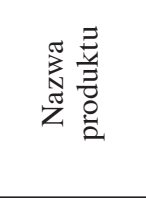 & 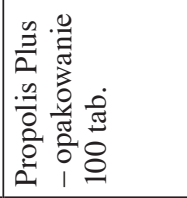 & 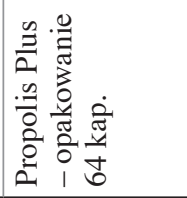 & 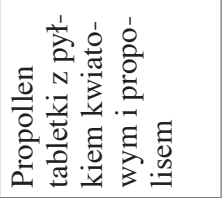 & 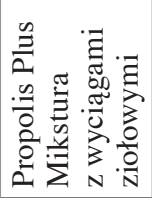 & 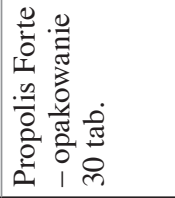 \\
\hline
\end{tabular}




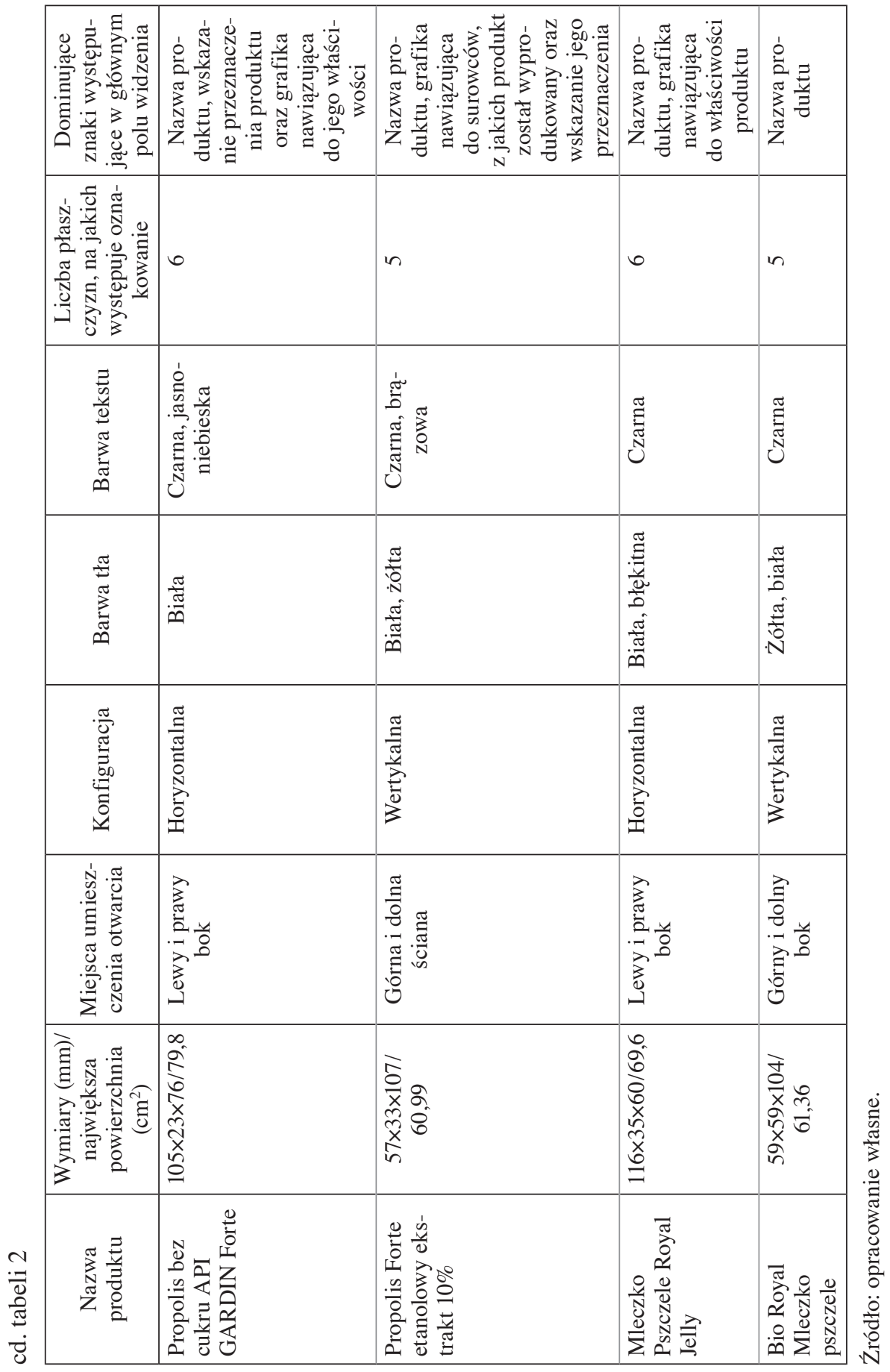


Zasadami, według których kwalifikowano wybrane znaki obligatoryjne do badań, były: wysoka ważność informacji, poziom określonych nieprawidłowości wynikający z badań prowadzonych wśród konsumentów suplementów diety (rys. 1) oraz znaczenie informacji z punktu widzenia bezpieczeństwa użytkowania produktu [Lisińska-Kuśnierz i Kabaja 2015].

\section{Wyniki badań}

Zgodnie z przedstawionymi kryteriami (tabela 1) przeprowadzono ocenę każdego ze znaków. Do badania użyto typometru DCS Typo+Lithometer firmy grafipress $\mathrm{GmbH} \mathrm{z} \mathrm{Karlsruhe.} \mathrm{Pomiarów} \mathrm{wymagających} \mathrm{precyzji} \mathrm{(np.} \mathrm{rozmiar}$ czcionki) dokonano z użyciem lupy o ośmiokrotnym powiększeniu. Do obliczenia wyników wykorzystano program Excel 2010. Uzyskane wyniki dla poszczególnych opakowań przedstawiono w tabeli 3.

Tabela 3. Wyniki oceny TVScore dla wybranych produktów

\begin{tabular}{|l|c|c|c|c|c|c|}
\hline \multirow{2}{*}{ Nazwa produktu } & \multicolumn{7}{c|}{ Liczba TVScore dla znaków } \\
\cline { 2 - 8 } & I & II & III & IV & V & Suma \\
\hline Propolis Plus - opakowanie 100 tab. & 3 & 5 & 7 & 4 & 4 & 23 \\
\hline Propolis Plus - opakowanie 64 kap. & 3 & 3 & 6 & 3 & 3 & 18 \\
\hline $\begin{array}{l}\text { Propollen tabletki z pyłkiem kwiato- } \\
\text { wym i propolisem }\end{array}$ & 7 & 6 & 9 & 7 & 6 & 35 \\
\hline $\begin{array}{l}\text { Propolis Plus Mikstura z wyciągami } \\
\text { ziołowymi }\end{array}$ & 3 & 10 & 8 & 7 & 10 & 38 \\
\hline Propolis Forte - opakowanie 30 tab. & 3 & 4 & 11 & 4 & 4 & 26 \\
\hline $\begin{array}{l}\text { Propolis bez cukru API GARDIN } \\
\text { Forte }\end{array}$ & 3 & 6 & 6 & 8 & 5 & 28 \\
\hline $\begin{array}{l}\text { Propolis Forte etanolowy ekstrakt } \\
\text { 10\% }\end{array}$ & 3 & 4 & 4 & 6 & 4 & 21 \\
\hline Mleczko Pszczele Royal Jelly & 2 & 3 & 5 & 3 & 3 & 16 \\
\hline Bio Royal Mleczko pszczele & 3 & 3 & 3 & 5 & 3 & 17 \\
\hline
\end{tabular}

Objaśnienia: I - data minimalnej trwałości, II - sposób stosowania, III - wykaz wszystkich składników, IV - ostrzeżenie dotyczące nieprzekraczania zalecanej porcji do spożycia w ciągu dnia, $\mathrm{V}$ - informacja dotycząca porcji produktu zalecanej do spożycia w ciągu dnia.

Źródło: opracowanie własne.

Na podstawie wyników oceny stwierdzić można, że najmniej odstępstw od założeń optymalnej typografii mają opakowania produktów: Mleczko Pszczele 
Royal Jelly - 16 TVScore, oraz Bio Royal Mleczko - 17 TVScore. Tuż za nimi znalazł się Propolis Plus - opakowanie 64 kap., który uzyskał ocenę 18 TVScore. Czwartą ocenę uzyskało opakowanie Propolis Forte etanolowy ekstrakt 10\% 21 TVScore. Najgorzej oceniono opakowanie Propolis Plus Mikstura z wyciągami ziołowymi - 38 TVScore.

Opakowania, które uzyskały dwa najlepsze wyniki, charakteryzują się umiarkowaną, stonowaną kolorystyką. Na ich powierzchni nie występuje zbyt wiele elementów grafiki i ilustracji. Opakowania te cechują się niewielką ilością znaków fakultatywnych. W porównaniu z innymi badanymi produktami ich wymiary i pole powierzchni należą do największych.

Szata graficzna produktu, który uzyskał najsłabszą ocenę, jest zbyt bogata. Jego wąskie i długie płaszczyzny wydają się zbyt małe do umieszczania pełnych zdań i stwierdzeń tworzących obligatoryjne oznakowanie. Dwie z bocznych płaszczyzn zajmuje jednakowa grafika z nazwą produktu i obrazem nawiązującym do jego składu. Świadczy to o złym wykorzystaniu dostępnej powierzchni, która jest w tym przypadku bardzo ograniczona - opisywane opakowanie ma najmniejsze wymiary i pole powierzchni całkowitej.

Przeprowadzona analiza pozwoliła także na określenie, w przypadku jakich znaków przeciętnie występuje najwięcej odstępstw od optymalnych parametrów. Były to przede wszystkim wykaz wszystkich składników oraz ostrzeżenie dotyczące nieprzekraczania zalecanej porcji do spożycia w ciągu dnia.

Na podstawie analizy oceny kryteriów przeprowadzonego badania TVScore stwierdzić można, że w badanej grupie suplementów diety najwięcej nieprawidłowości występowało w zakresie rozmiaru czcionki i rodzaju powierzchni opakowania. W zdecydowanej większości rozmiar czcionki wynosił 6 pkt, chociaż zdarzała się również czcionka o rozmiarze 5 pkt. Powierzchnię wszystkich opakowań oceniono jako lekko połyskującą, sprawiającą niewielkie trudności w czytaniu. Spośród wszystkich przyznanych punktów TVScore aż 39\% wynikało ze zbyt małego rozmiaru czcionki, a 19\% powodowała połyskująca powierzchnia opakowania, na której umieszczano oceniane informacje. Otrzymane wyniki korespondują z wynikami badań innych autorów, którzy również za największe trudności w dostępie do informacji uznawali zbyt małe rozmiary czcionek [Lisińska-Kuśnierz 2009] oraz błyszczące opakowanie [Ratkovska, Wojtasik i Kuchanowicz 2008]. Zbieżność uzyskanych wyników z wynikami innych autorów potwierdza skuteczność metody TVScore.

W ocenianym materiale badawczym nie odnotowano nieprawidłowości, które dotyczyłyby: stosowania rewersu druku, nieodpowiedniego kontrastu, nadużywania majuskuły lub kapitalików.

Zgodnie z interpretacją M.A. Mackey i M. Metz [2007] uzyskanie tak wysokich wartości TVScore oznacza, że dostępne na rynku opakowania suplementów 
diety zapewniają bardzo niską informacyjność i powinny zostać przeprojektowane.

\section{Podsumowanie}

Wielu autorów podkreśla potrzebę znalezienia równowagi między ilością i jakością informacji umieszczanych na opakowaniach a potrzebami informacyjnymi nabywców. Liczne badania potwierdzają niezadowolenie konsumentów ze znakowania opakowań produktów. Wymaga to przede wszystkim zaangażowania podmiotów wprowadzających produkty na rynek i budzenia w nich świadomości i potrzeby dostosowywania wyglądu opakowań do oczekiwań i możliwości konsumentów.

Wyniki badań wskazują na małą aktywność producentów w zakresie zaspokajania tej grupy potrzeb nabywców. Może to wynikać z nieświadomości tych podmiotów lub nadmiernej ufności w kompetencje firm zewnętrznych, którym powierza się projektowanie opakowań. Szczególnie niepokojące wydają się sygnały o niekompletnym oznakowaniu obligatoryjnym. W ten sposób demonstruje się skrajnie niewłaściwe podejście do kwestii związanych ze znakowaniem i wskazuje na słabość oraz nieefektywność działania jednostek administracji publicznej, które nadzorują ten obszar.

Jedną z przyczyn tak niekorzystnej sytuacji na rynku może być brak odpowiednich narzędzi umożliwiających weryfikację poprawności znakowania. Przedstawiona w niniejszej pracy metoda TVScore wydaje się odpowiednia do tego celu. Jej zastosowanie pozwoliło na ocenę wybranych opakowań suplementów. Ponadto metoda TVScore dała możliwość identyfikacji przyczyn ograniczających informacyjność badanych opakowań. W przyjętym materiale badawczym była to zbyt mała czcionka oraz połyskująca powierzchnia produktów.

Za powszechnym stosowaniem metody TVScore przemawia wiele argumentów. W porównaniu z innymi narzędziami jest zdecydowanie tańsza, prostsza i nie wymaga kosztownej aparatury. Metoda ta może być wykorzystana już we wstępnych fazach projektowania opakowania.

Od dłuższego czasu jakość znakowania jest podobna, a wprowadzane nowe akty prawne nie wydają się wpływać na ogólną poprawę sytuacji. W związku z tym podejmowane powinny być dalsze działania mające na celu podnoszenie poziomu świadomości w kręgach związanych z projektowaniem opakowań oraz poszukiwaniem nowych metod mogących weryfikować poprawność i dostępność przekazywanych przez nie informacji. 


\section{Literatura}

Ankiel-Homa M. [2012], Wartość komunikacyjna opakowań jednostkowych, Wydawnictwo Uniwersytetu Ekonomicznego w Poznaniu, Poznań.

Cholewa-Wójcik A., Kawecka A. [2015], The Influence of Effectiveness of Packaging Elements on the Consumers' Preferences with the Use of Marketing Eye-Tracking Technique, „Modern Management Review”, vol. XX, nr 22(1).

Klonowska-Matynia M. [2010], Opakowania produktów na rynku mleczarskim. Studium empiryczne, Wydawnictwo Uczelniane Politechniki Koszalińskiej, Koszalin.

Lisińska-Kuśnierz M. [2009], Oczekiwania i potrzeby konsumentów w zakresie informacyjności opakowań do czekolady mlecznej, „Opakowanie”, nr 9.

Lisińska-Kuśnierz M., Kabaja B. [2015], Information Inaccuracies in Dietary Supplement Labeling as Assessed by Consumers [w:] Food Product Quality and Packaging Quality. Current State and Challenges, eds A. Cholewa-Wójcik, A. Kawecka, University of Maribor, Faculty of Logistics, Celje, Slovenia.

Lisińska-Kuśnierz M., Ucherek M., Borusiewicz A. [2008], Opakowanie jednostkowe jako nośnik informacji dla konsumenta, Temat badawczy nr 18/KOT/1/2008, Uniwersytet Ekonomiczny w Krakowie, Kraków (maszynopis).

Mackey A.M., Metz M. [2007], Readability of Food Product Labels. Appendices for the Final Report, Consumer Interest Alliance, Toronto, http://www.ciai.ca/ website_reports/Food_label_1-29_TVScore.pdf (data dostępu: 10.07.2015).

Metz M. [1996], Preferences of Consumers Age 50+ for Typography of Product Instruction Labels, McGill University, Montreal, http://www.nlc-bnc.ca/obj/s4/f2/dsk2/ftp03/ NQ30338.pdf (data dostępu: 10.07.2015).

Miśniakiewicz M., Pycek M. [2014], Analiza determinant wyboru produktów spożywczych marek własnych i określenie poprawności znakowania ich opakowań, ,Zeszyty Naukowe Uniwersytetu Ekonomicznego w Krakowie", nr 3(927), http://dx.doi. org/10.15678/ZNUEK.2014.0927.0307.

Nestorowicz R. [2014], Architektura informacji na opakowaniach produktów żywnościowych a skuteczność komunikacji marketingowej, „Marketing i Rynek”, nr 4.

Ozimek I. [2002], Znaczenie informacji podawanych na opakowaniu produktu żywnościowego, „Przemysł Spożywczy”, nr 10.

Ozimek I., Tomaszewska-Pielacha T. [2011], Czynniki wpływajace na czytanie przez konsumentów informacji zamieszczanych na opakowaniach produktów żywnościowych, Studia i Materiały Polskiego Stowarzyszenia Zarządzania Wiedzą, Bydgoszcz.

Paterson D.G., Tinker M.A. [1940], How to Make Type Readable, Harper and Brothers, New York.

Piecyk M., Marczuk-Daniluk M. [2011], Znakowanie produktów spożywczych w aspekcie alergii pokarmowej w opinii konsumentów, Zeszyty Naukowe Uniwersytetu Ekonomicznego w Poznaniu, nr 206, Poznań.

Ratkovska B., Wojtasik A., Kuchanowicz H. [2008], Łatwość rozpoznawania produktów spożywczych do stosowania $w$ diecie bezglutenowej na podstawie informacji na etykietach, „Bromatologia i Chemia Toksykologiczna”, vol. XLI, nr 3.

Rozporządzenie Parlamentu Europejskiego i Rady (UE) nr 1169/2011 z dnia 25 października 2011 r. w sprawie przekazywania konsumentom informacji na temat żywności, zmiany rozporządzeń Parlamentu Europejskiego i Rady (WE) nr 1924/2006 i (WE) nr 1925/2006 oraz uchylenia dyrektywy Komisji 87/250/EWG, dyrektywy Rady 
90/496/EWG, dyrektywy Komisji 1999/10/WE, dyrektywy 2000/13/WE Parlamentu Europejskiego i Rady, dyrektyw Komisji 2002/67/WE i 2008/5/WE oraz rozporządzenia Komisji (WE) nr 608/2004, Dz.U. UE L 304/18.

Sprawozdanie roczne 2014 [2015], Inspekcja Jakości Handlowej Artykułów Rolno-Spożywczych, Warszawa, http://www.ijhar-s.gov.pl/pliki/A-pliki-z-glownegokatalogu/ ethernet/2015/maj/Sprawozdanie\%20roczne\%20 2014.pdf (data dostępu: 10.07.2015).

Sutherland S.W. [1989], Miles Albert Tinker and the Zone of Optimal Typography, University of Washington, Washington.

Tinker M.A. [1963], Legibility of Print, Iowa State University, Ames, Iowa.

Tomaszewska-Pielacha M., Ozimek I. [2011], Czytelność i zrozumiałość informacji zamieszczanych na opakowaniach żywności w opinii konsumentów, „Problemy Higieny i Epidemiologii", nr 92(4).

Ucherek M. [2009], Fakultatywne znakowanie środków spożywczych jako element ksztattowania decyzji nabywczych konsumentów, „Marketing i Rynek”, nr 10.

\section{Possible Uses of TVScore Method for Assessing Package Labeling - the Example of Dietary Supplements} (Abstract)

In the light of the growing importance of product packaging in a producer's communication with consumers, it is of the utmost importance that the information packaging is meant to convey be made as accessible as possible. The aim of this article was to introduce the TVScore method, adapt it to the conditions in Poland and implement with its use an assessment of the product labeling of chosen dietary supplements. This group was chosen for the research for several reasons, including the steady growth in sales the market has seen and the consistently low level of satisfaction consumers feel with regard to supplement packaging. Nine items were selected to evaluate the packaging of dietary supplements marketed to boost immunity to illness. The results show that the largest number of cases with labeling deemed problematic involved packaging with fonts that were too small to read and packaging with a glossy surface.

Keywords: packaging, labeling, research method, legibility, visibility. 